\title{
A new paradigm for Political Studies: competence-based teaching and learning*
}

\author{
Terrie R. Groth**
}

First publication online: 30 June 2015

\begin{abstract}
For some decades, students and scholars of Political Science have debated methodological differences, paradigmatic differences, and policy differences as they relate to curricula. Today, the real challenges facing the teaching of Political Science have less to do with content and much more to do with form and process. The next transformation in teaching and learning must address what kind of political scientist we wish to be, which kind of Political Science we need to create. ${ }^{1,2}$ Our argument advances in three moments. First, we sketch contemporary contexts for analyzing teaching and learning, musing about old and new paradigmatic/ methodological debates and the new social-technological contexts of undergraduate learning. Second, we discuss conceptions of competencies in the U.S., Europe, and in
\end{abstract}

* Manuscript originally presented at the 23rd IPSA World Congress 2014 (Montreal) in the Research Committee 33 (The Study of Political Science as a Discipline) panel "Paradigms and Historiography in Political Studies", Wednesday, 23 July, 17:00-18:45. A less complete version was presented at the 11th APSA Teaching and Learning Conference (Groth 2014). For a personal, reflective lament in a somewhat similar vein see Cox (2003). The analysis of the concept of competences draws heavily on the work of and personal discussions with Prof. Loussia Musse Felix, my colleague at the Law School at UnB and Coordinator for the Area of Law ALFA Tuning-Latin America.

** Professor, Institute of Political Science (IPOL), University of Brasília (UnB). E-mail: tgroth@unb.br Skype: terrie.r.groth2 This work is a collective effort on the part of the principal author and collaborating members of the undergraduate seminar Special Topics in Political Science 2: Teaching and Learning in Political Science (First Semester 2014) including: André Ferreira Freitas (andrefreitasdpg@gmail.com), Ítalo Leone Corrêa (italolcorrea@gmail.com), Fernanda Torres da Silva (nandinha_ts14@hotmail.com), Mariana Alves Barreto (malvesbarreto.3@gmail.com), Renato Bastos Abreu (renato260@hotmail.com), and Sthefani Lara dos Reis Rocha (sthefanilara@hotmail.com). Students are listed in alphabetical order by first name (Brazilian custom). Some additional bibliographical research and fact-checking was undertaken by my undergraduate research assistant Cristine Dias Rolim (Young Talents for Science Program - PJT-IC).

${ }^{1}$ Lisa Anderson,"Too Much Information? Political Science, the University, and the Public Sphere,” Perspectives on Politics 10 (2012): 385-396.

${ }^{2}$ Stephen G. Hartlaub and Frank A. Lancaster, "Teacher Characteristics and Pedagogy in Political Science,” Journal of Political Science Education 4, no 4 (2008): 377-393. 
relation to a specific Political Science program in Brazil. Third, we dare to sketch a "metaprofile" of the "good political scientist", modeled on the work of the ALFA Tuning Project of the European Commission and reflections on related Brazilian and Latin American experiences.

Keywords: Competences; paradigms; Political Science; teaching; learning; undergraduate education.

\section{Paradigmatic Contexts for Analyzing Teaching and Learning}

The main purpose of this paper is to introduce the question of competences into discussions of curricula and pedagogy in Political Science. More specifically, we are interested in charting how this emphasis on competences has migrated from Europe to Latin America and suggesting how the debate might be integrated into teaching and learning Political Science. We first present our vision of how the old paradigmatic fights that colored the practice of Political Science in the post-WWII era have left a legacy for teaching and learning. We then call attention to what might be a third paradigmatic revolution which impacts teaching and learning for all political scientists, regardless of their ideological orientation.

\section{Old Paradigmatic Fights in Political Science}

The organizing notion of paradigm became central by the 1970s; political theorists used to know who and where they were. Radical scholars coalesced around the concept as a means of developing a systematic critique of scientific objectivity and neutrality. Political scientists debated the relevance of paradigm in defining research directions; others concentrated on a critique of paradigms in existing political research. Questioning centered on the premises and biases of pluralism and by extension the foundations of developmentalism.

Times still call for a radical revision of Political Science. ${ }^{3,4}$ Yet the current impasse of our prevailing theories has not produced a more open climate to critical analyses nor freer competition of ideas. On the contrary,

${ }^{3}$ John E Trent, "Political Science 2010: Out of Step with the World? Empirical Evidence and Commentary," Paper prepared for the $21^{\text {st }}$ International Political Science Association World Congress, Santiago, Chile, July, 2009.

4 John E Trent, "Should Political Science Be More Relevant? An Empirical and Critical Analysis of the Discipline,” European Political Science 10 (2011): 191-209. 
Political Science clings to it previous dominant models while potential critics isolate themselves in a "radical malaise" (the incapacity to define and implement an alternative agenda for research and action). This ill-feeling relates to two interdependent and sequential crises: 1) the crisis of paradigms, 2) the crisis of "existing socialisms". ${ }^{5}$ We summarize our view of these crises here because, in our view, they constitute the forces that condition our efforts at rethinking teaching and learning.

\section{Crisis of Paradigms}

Beyond the increasing lack of fields of reference, the "crisis of paradigms" affecting all of the social sciences and humanities over the last quartercentury has led Political Science into a series of theoretical and methodological impasses.

In the passage from traditionalism to behavioralism, proponents of various paradigms or approaches battled for supremacy. The traditional approach to political study emphasized the interrelation of fact and value in sweeping historical or cultural treatments, static and descriptive categories, and a legal-formal focus on state institutions, parties and elections, leaders and individual cases. The behavioral Chicago School, in reaction to this form of explication, argued in favor of new methods of analysis. Focusing on the goal of explaining actual political behavior and hoping to successfully imitate the procedures and models of the natural sciences, the behavioral emphasis included a search for regularities, an emphasis on verification, techniques and quantification, the attempt to separate facts from values, and the interdisciplinary systematization of social research.

The reaction to such scientism is well-known. U.S. "post-behavioralism" of the 1960s and 70s represented a reaction to the scientific revolution proposed by behavioralism and favored action and relevance in contrast to detachment and "pure science." Controversy focused around the issues of placing social substance before investigative techniques, the ideological conservatism of behavioralism, the myth of a neutral social science, and the social responsibility of the academic scientist.

5 Terrie R Groth,'Diagnosing and Treating the Radical Malaise" (paper presented at the XVIth International Congress of the Latin American Studies Association, Washington, DC, April 4-6, 1991). 
In Brazil, this paradigmatic debate did not resonate ${ }^{6,7,8}$ for a brief early debate about the "autonomy" of Brazilian Political Science). Emerging from the other social sciences in the 1970s, Brazilian Political Science has not strayed far from its North American roots, either in theory or methodological commitments. ${ }^{9}$ More recent assessments of the state of development of Brazilian Political Science continue to largely confirm this. ${ }^{10}$ Looking at political theory specifically, ${ }^{11}$ identify seven "principal topics" that occupy Brazilian political theorists: 1) theories of justice, distributive justice, and international justice; 2) democratic theory, political liberalism, and contemporary constitutionalism; 3 ) the debate over deliberative democracy; 4) the so-called "return" to republicanism; 5) theoretical evaluations of civil society practices; 6) the debate around theories of recognition, and 7) the crisis in representation and new theories of political representation. This list is suspiciously similar to the tendencies highlighted by the late Iris Marion Young ${ }^{12}$ in a sweeping review of contemporary political theory. ${ }^{13}$ Differences among Brazilian political scientists are probably more generational than political/ideological. ${ }^{14}$

${ }^{6}$ Bolivar Lamounier, "Pensamento Político, Institucionalização Acadêmica e Relação de Dependência no Brasil," Dados 23, no 1 (1980): 29-57.

7 Fábio W Reis, "O Grifo É Nosso! Academia, Democracia e Dependência," Dados 23, no 1 (1980): 59-77.

8 Wanderley Guilherme dos Santos, "A Ciência Política na América Latina (notas preliminares de autocrítica)," Dados 23, no 1 (1980): 15-27.

9 Maria Cecília Spina Forjaz, "A Emergência da Ciência Política Acadêmica no Brasil: Aspectos Institucionais,” Revista Brasileira de Ciências Sociais 35 (1997): 101-120.

${ }^{10}$ Renato Lessa, "O Campo da Ciência Política no Brasil: uma Aproximação Construtivista," in Horizontes das Ciências Sociais no Brasil: Ciência Política, ed. Carlos Benedito Martins and Renato Lessa (São Paulo: ANPOCS, 2010, 13-49.

${ }^{11}$ Cícero Araújo and San R Assumpção, “Teoria Política no Brasil Hoje,” in Horizontes das Ciências Sociais no Brasil: Ciência Política, ed. Carlos Benedito Martins and Renato Lessa (São Paulo: ANPOCS, 2010), 61-75 .

${ }_{12}$ Iris Marion Young, "Political Theory: An Overview," in A New Handbook of Political Science, ed. by Robert E. Goodin and Hans-Dieter Klingemann (Oxford: Oxford University Press, 1996), 479-502.

${ }^{13}$ Her list: 1) social justice and welfare rights theory; 2) democratic theory; 3) feminist political theory; 4) postmodernism; 5) new social movements and civil society, and 6) liberalism and communitarianism.

${ }^{14}$ Bolivar Lamounier, “A Ciência Política no Brasil: Roteiro para um Balanço Crítico," in A Ciência Política nos Anos 80, ed. Bolivar Lamounier (Brasília, DF: Editora UnB, 1982), 407-433. 


\section{Crisis of "Existing Socialisms"}

A second simultaneous crisis contributing to the radical malaise relates to the political and social upheavals in the Soviet Union and Eastern Europe. The apparent end of the statist variant of socialist development left even mainstream political scientists out in the analytical cold. Few Soviet scholars entertained models admitting the possibility of such rapid and profound change. Already marginalized progressives were further distanced from the discussion of alternative futures for the East and the rest of the world. In the case of comparative politics and Latin Americanists, this feeling of marginalization was more indirect but nevertheless serious. While radical attentions focused on another region, commitments to popular struggles and involvement in anti-interventionist or anti-imperialist movements carried with them at least the implicit embrace of some kind of a revolutionary nationalist or socialist future. Regardless of an individual's personal degree of anti-Stalinism, events in the socialist world carried unnerving implications for radical political scientists.

As the political and ideological differences among political scientists have played out, theoretical and normative positions for the next generation appear homogenized and/or irrelevant. Political Science in the twenty-first century seems not to require political scientists anymore. If Political Science is what political scientists "do", then their teaching and their students" learning are also issues beyond critical reflection (except by a relatively small but dedicated subgroup of the profession). ${ }^{15}$ This distinction leads to the concept of competences as a way of seeking a new paradigm for political studies.

\section{New Paradigmatic Fights in Teaching and Learning}

We speculate next about how teaching and learning have been transformed since (some of us) were undergraduates. The changes are too numerous to cover, any one of which could spark other papers (the assault on tenure, the commodification of higher education, etc.). We restrict our commentary to the social and cognitive impacts of technological innovations since these are

15 An active and inclusive group of political scientists emerged around 2000 and slowly galvanized the American Political Science Association (APSA) to foment annual Teaching and Learning Conferences in Political Science since 2004. These efforts led to the founding of the Journal of Political Science Education and inspired collaboration with the Brazilian Political Science Association (ABCP) which has formed a Working Group on Teaching Learning active within the Association since 2010. 
the real challenges to teaching and learning that link (or divide) professors and their students. In relation to our own Political Science program, we used to think that what was needed a rethinking of the "canons" of the profession in strict curricular terms (revising content, reordering the presentation of courses, adding new ones, complementing the classroom with ancillary activities, etc. ${ }^{16}$ ). More recently, as a result of our exposure to the concept of competence learning, we wonder if the previous assessment was just so much tinkering. We need to think about how the world and our students have changed and what uncomfortable changes are required of ourselves. ${ }^{17}$

Much has already been written about the so-called "post-industrial" society and "post-modern" culture and politics. These airy debates need to be better informed by the technological world of our students. ${ }^{18,19}$ An estimated

16 Terrie R Groth, "Rethinking Political Science as Discipline: Teaching and Learning at the University of Brasília" (paper prepared for delivery at the 2000 Annual Meeting of the American Political Science Association, Marriott Wardman Park Hotel, Washington, DC, August 31-September 3, 2000).

${ }_{17}$ Philip C. Abrami, Gretchen Lowerison, and Eva M Bures, "Introduction to the Special Issue on Postsecondary Instruction: The Old Science of Phrenology and the New Science of College Teaching," Educational Research and Evaluation: An International Journal on Theory and Practice 10, no 4-6 (2004): 289-301.

${ }_{18}$ Howard Gardner and Davis Katie, The App Generation: How Today's Youth Navigate Identity, Intimacy, and Imagination in a Digital World (New Haven: Yale University Press, 2013).

${ }^{19}$ Ironically, our sources for this section are culled from the Internet! To wit: http://royal. pingdom.com/2010/10/22/incredible-growth-of-the-internet-since-2000; http://itu.int/net/ pressoffice/press-releases/2010/39.aspx; http://www.nytimes.com/2010/04/11/ weekinreview/11 giridharadas.html; http://www.time.com/time/magazine/ article/0.9171.2062452.html; http://facebook.com/press/info.php?statistics; http://www.theblaze. $\mathrm{com} /$ stories/its-official-majority-of-americans-are-on-facebook; http://mashable. com/2010/12/29/2010-the-year-facebook-dethroned-google-as-king-of-the-web-stats/; http:// www.enn.ie/story/show/101206002; http://facebook.com/press/info,php?statistics; http://www. time.com/time/specials/packages/article/0.28804.2036683_2037183_2037185.00.html; http:// nytimes.com/2010/10/31/technology/31ev.html; http://gizmodo.com/5712857/over-25-billiontweets-were-sent-in-2010-and-the-ipad-was-the-top-tech-subject; http://www.briansolis. com/2010/11/who-are-all-of-these-tweeple; http://en.wikipedia.org/wiki/List_of_countries_bypopulation; http://youtube-global.blogspot.com/2010/11/great-scott-over-35-hours-of-video. html; http://phx.corporate-ir.net/phoenix.zhtml?c=176060\&p=irol-newsArticle \&ID=1565581; http://en.wikipedia.org/wiki/Wikipedia-Size_comparisons\#Comparison_of_encyclopedias; http://blog.flickr.net/en/2010/09/19/5000000000/; http://www.usatoday.com/tech/news/201007-21-facebook-hits-500-million-users_N.htm; http:/www.businesswire.com/news/ home/20101006006722/em/Digital-Birth-Online-World; http://blogs.forrester.com/sarah_ rotman_epps/11-01-04-us_tablet_sales_will_more_than_double_this_year; http://youtube.com/ watch?v=6mCkbrYKQyI"; httP;//techcrunch.com/2011/06/14/angry-birds-downloads-250million-magi/; http://ww.emc.com/collateral/demos/microsites/idc-digital-universe/iview.htm; 
5 billion cell phones are in service today, giving more people access to mobile conversations than they have to a clean toilet. In the U.S., $25 \%$ of homes have a cell phone only. Two billion people are on the Internet at any given moment with 750 million on Facebook ( 1 in 9 of us worldwide). Things got more complicated with Twitter with 200 million people sending 100 million tweets per day. If Facebook and Twitter were countries, they would rank $3^{\text {rd }}$ and $6^{\text {th }}$ respectively in global population.

Visually, we are also affected by the information revolution. Thirty-five hours of video are uploaded to YouTube every minute, material equivalent to 176,000 Hollywood releases per week. Flickr users have uploaded 5 billion pictures and there are another 50 billion on Facebook. Almost a third of all people under 25 get all or most of their television on-line. Ninety-two percent of American children have an on-line presence by the time they turn 2 . Digital activity becomes more mobile as 80 million Americans are expected to own an iPad. Most people are glued to their cell phones or similar devices, downloading 300 million mobile applications in 2009 and 5 billion the following year (that includes 250 million in Angry Birds alone). We circulate 247 billion emails every day with $80 \%$ of them considered to be spam, Trojans or viruses. A bewildering 6.1 trillion text messages were sent in 2012. In the U.S. (and probably Brazil), $87 \%$ of all teenagers text and emit an average of 3,339 messages per month.

Informationally, beyond all this yakking to each other, there are quite a lot of data out in the virtual realm. Kindle now outsells all hardbacks and paperbacks combined on Amazon. Wikipedia (the universal source of all undergraduate academic knowledge) is comprised of 3.6 million articles in English alone. The volume of digital information worldwide will increase 44 times from now until 2020.

Practically all of us have welcomed these devices and changes into our lives and bodies over the last generation. We "integrate technology into the classroom" (a theme at annual APSA Teaching and Learning Conferences), but the nature of education does not seem to change. Eighty-percent of U.S. high school students' work is low-level (definitional memorization), the sort of information easily located on Google in fractions of seconds. The average U.S. $5^{\text {th }}$ grader gets five times the instruction in basic skills versus problemsolving or reasoning. If we compared photographs of typical secondary or

http://web2expo.blip.tv/file/1277460/; http://www.learningsolutionsmag.com/articles/608/ dispatch-from-the-digital-frontier-digital-dust-bunnies"; http://www.itu.int/net/pressoffice/ press_releases/2010/39.aspx; http://www.pewinternet.org/Reports/2010/Cell-Phones-andAmerican-Adults.aspx; http://mashable.com/2010/10/14/nielsen-texting-stats; http://bigthink. com/ideas/30621. 
higher education classrooms from the late nineteenth-century until today, the only notable difference would be changing styles of dress (today with the addition of laptops). One estimate is that by 2019, half of U.S. high school courses will be offered entirely on-line. What level of thinking are we to expect of them when they become university students?

We observe the same technological presence and transformation in Brazil, although we cannot document the magnitude as yet. What should interest us is how these accelerated changes have impacted us and our students. Our students are cognitively different from us. They learn and think in ways far removed from our traditional training. ${ }^{20} \mathrm{We}$ are forced to think about teaching and learning outside the confines of Political Science and beyond the routines of curriculum and classroom. It would be naive to suggest that the genie be recorked in the bottle. But it would be fatal for us as pedagogues to ignore how we have been cognitively rewired over a generation.

Tech journalist Nicholas Carr $^{21}$ unleashed controversy in a 2008 article by asking "Is Google Making Us Stupid?"22 More recently, ${ }^{23}$ he has moved to analyze the Internet as a whole in the light of contemporary neuroscience. The upshot of the research upon which he reflects is twofold. First, the Internet teaches us how to read differently. We seek and sift information very differently than a generation or two ago. Our senses react differently to reading webpages ${ }^{24},{ }^{25},{ }^{26}$ and being led through hypertext. ${ }^{27,28,29} \mathrm{We}$ become

${ }^{20}$ Darrell Driver, Kyle Jette, and Leonard Lira, "Student Learning Identities: Developing a Learning Taxonomy for the Political Science Classroom," Journal of Political Science Education 4, no 1 (2008): 61-85.

${ }^{21}$ Nicholas Carr, "Is Google Making Us Stupid?," Atlantic Monthly (2008).

${ }^{22}$ See also Gary Small and Gigi Vorgan, iBrain: Surviving the Technological Alteration of the Modern Mind (New York: Collins, 2008).

${ }^{23}$ Nicholas Carr, The Shallows: What the Internet Is Doing to Our Brains (New York: W.W. Norton \& Company, 2011).

${ }^{24}$ Charles E. Connor, Howard Egeth E., and Steven Yantis, "Visual Attention: BottomUp versus Top-Down," Cognitive Biology 14 (2004): 850-52.

${ }^{25}$ Jakob Nielsen, "F-Shaped Pattern fo Reading Web Content," Alertbox, 2006, accessed April 17, 2015, www.useit.com/alertbox/reading_pattern.html.

${ }^{26}$ Jakob Nielsen, "How Little Do Users Read?," Alertbox, 2008, accessed May, 62015, www.useit.com/alertbox/percent-text-read.html.

27 Jean-François Rouet and Jarmo J. Levonen, "Studying and Learning with Hypertext: Empirical Studies and Their Implications," In Hypertext and Cognition, ed. Levonen Rouet, Andrew Dillon and Rand J. Spiro (Mahwah, NJ: Erlbaum, 1996).

${ }^{28}$ D. S. Niederhauser et al., "The Influence of Cognitive Load on Learning from Hypertext," Journal of Educational Computing Research 23, no 3 (2000): 237-255.

${ }^{29}$ Diana DeStefano and Jo-Anne LeFevre, "Cognitive Load in Hypertext Reading: A Review," Computers in Human Behavior 23, no 3 (2007): 1616-1641. 
less able to engage in "deep reading", i.e., not just comprehending content but rethinking it in our own fashion along the way. According to some, the structure of the Internet encourages constant distraction, ${ }^{30}$ which inhibits analytical thinking in the long-run. ${ }^{31}$

Second, "deep thinking" becomes more difficult. Drawing on contemporary research on memory and brain chemistry, ${ }^{32,33,34,35}$ Carr argues that as our attention span shortens our short-term "working memory" becomes overloaded. The result is that the formation of long-term memory (which takes time and is necessary for analysis, cumulative comparison and reflection) is disturbed. The use of information technology imperceptibly rewires our neural pathways. ${ }^{36,37} \mathrm{We}$ and our students probably believe that today we know more, think faster, and use the new technologies for our own ends when in fact experimental studies reveal the opposite to be true. If we and our students do not think the way we used to, imagine how this might affect the way we write ${ }^{38}$ or what we publish. ${ }^{39}$

\section{Undergraduate Political Science: US and Brazilian Differences}

Turning to the specific question of teaching and learning about politics, we should remind ourselves that university teaching in general also sets certain institutional cultural constraints. In the case of Brazilian higher

${ }^{30}$ Maggie Jackson, Distracted: The Erosion of Attention and the Coming Dark Age (Amherst, NY: Prometheus, 2008).

${ }^{31}$ Marc G. Berman, John Joanides, and Stephen Kaplan, "The Cognitive Benefits of Interacting with Nature," Psychological Science 19, no 12 (2008): 1207-1212.

32 Joseph LeDoux, Synaptic Self: How Our Brains Become Who We Are (New York: Penguin, 2002).

${ }^{33}$ Eric R Kandel, In Search of Memory: The Emergence of a New Science of Mind (New York: Norton, 2006).

${ }^{34}$ Torkel Klingberg, The Overflowing Brain: Information Overload and the Limits of Working Memory, trans. Neil Betteridge (Oxford: Oxford University Press, 2009).

${ }^{35}$ Bruce E Wexler, Brain and Culture: Neurobiology, Ideology, and Social Change (Cambridge, MA: MIT Press, 2006).

${ }^{36}$ Gary Small et al., "Your Brain on Google: Patterns of Cerebral Activation during Internet Searching," American Journal of Geriatric Psychiatry 17, no. 2 (2009): 116-126.

${ }^{37}$ Langdon Winner, "Technologies as Forms of Life," in Readings in the Philosophy of Technology, ed. David M. Kaplan (Lanham, MD: Rowman \& Littlefield, 2004).

38 J.C Niyíri, "Thinking with a Word Processor," in Philosophy and the Cognitive Sciences, ed. R. Casati (Vienna: Hölder-Pichler-Tempsky, 1994).

39 James A Evans, "Electronic Publication and the Narrowing of Science and Scholarship," Science 321 (2008): 395-399. 
education, these constraints are rather peculiar. The primary author, having taught in both environments, feels more clearly the constraints on a professor's work and the classroom. Thus, we provide a bit of context about teaching Political Science to undergraduates in Brazil. ${ }^{40}$

The job of a university professor at a Brazilian public university is defined by the Law of Directives and Bases (Lei de Diretrizes e Bases), enabling legislation for public education at all levels enacted after the adoption of a new federal constitution in 1988. The function of a university professor is defined as a seamless realization of a so-called "tripod" of teaching, research, and extension (service) work. This probably sounds somewhat familiar to U.S. (if not European) academicians. The problem is that this definition has become a kind of mantra for those defending tuitionfree public higher education in Brazil. This tends to equate all three of these functions/objectives and create a standard for performance that is in practice impossible to meet. In truth, research weighs far more in career advancement, teaching loads are expected to be equal for everyone (regardless of productivity), and as a result extension work runs a distant third in the personal priorities of the average professor.

Nevertheless, the maintenance of the myth of "indissociability" remains an article of faith among university administrators, professors' unions, and

40 The University of Brasília (UnB) opened its doors in 1962, imagining itself as a university for all of Latin America. Today it boasts around 38,000 students (mostly from Brazil and the Lusophone community) distributed over 22 Schools and Institutes, 52 departments, 76 daytime and nighttime undergraduate programs, 87 graduate degree programs, and 57 professional specialization courses.

By U.S. standards, UnB is a "state school" of some considerable size. It is one of the flagship institutions, ranked in 2000 as the best in the nation based on egress test scores and program evaluations of its major professional courses. Currently, within the federal system of higher education comprised of 54 federal universities, it is similarly subject to national policy dictates in the area and almost totally dependent for its basic payroll and operating expenditures on public budgets. Brazilian public universities are tuition-free and access is guaranteed via competitive standardized entrance exams conducted by each institution. UnB was also a pioneer in the introduction of quotas for afro-descendant and indigenous students at the undergraduate and graduate levels.

$\mathrm{UnB}$ is staffed by about 2300 professors, the vast majority of these PhDs with full-time exclusive contracts. Political Science faculty (around 30 to 35 permanent and temporary contract members) are drawn from different generations, experiences, and nationalities. Almost all possess the doctorate, earned for the most part in the U.S., the U.K. or France. A dwindling minority holds the M.A. as the terminal degree. Most are full-time appointments with academia as their only career commitment. The younger part-time replacement faculty in their late $20 \mathrm{~s}$ and early 30 s are usually drawn from our own MA and PhD students. The oldest members have been at UnB for around fifteen to twenty years and a sizeable plurality range in the $40 \mathrm{~s}$ and $50 \mathrm{~s}$, most contracted in the last five to ten years. 
some departments. The constraint of this academic culture complicates all academic activities and ignores the objective realities of the career today. Research is difficult in the best of times for the social sciences and humanities with funding concentrated in the hands of two federal government agencies. Teaching is becoming all the more Fordist in conception as full-time faculty are required to teach 2-3 courses over a 15+ week semester. Research is demanded, but teaching loads are inviolable; release depends very much on the climate and policy of your department. As a result, professors and students are engaged in dispatching numbers of credits and not seeking or thinking about the sum of contents or competences that should be acquired. Extension or service learning projects, even when linked to research, constitute the shortest leg of the "tripod" and remain the targets of numerous discriminations. Reaching beyond the classroom and the university may make you a more colorful character, but probably connotes a less "serious" member of the profession. And, of course, there is a fourth unseen or unsung leg to this "tripod": administering the Weberian bureaucratic nightmare of the university in your spare time. ${ }^{41}$

The sum of these competing and conflicting pressures creates a definition of a university professor to which no one can measure up. The myth of indissociability may have seemed nobler thirty or so years ago when class sizes were smaller, salaries less eroded, and the generation of knowledge less complex and globalized. But today, this rigid vision of the profession only

${ }^{41}$ This institutional setting weighs heavily on our B.A. program which is far more coursework intensive and theoretically dense than a U.S. major. The Undergraduate Program was created in 1989 to offer a B.A. in Political Science (separate from Social Sciences), formally recognized by the Ministry of Education in 1994. The Political Science B.A. is a largely self-contained four-year program, unlike majors at U.S. colleges. There is currently no two-year "liberal arts" or general education prelude to the selection of the major. The student approved in the entrance exam jumps directly into Political Science, albeit with some introductory social science courses. The curriculum, like most at UnB, is composed of required ("obligatory"), optional ("selective obligatory," usually within the program), and general campus ("free module") courses totaling about 180 credits (one course is usually equal to 4 credits). Probably 80 to $90 \%$ of the courses our students take are in the institutional and disciplinary world of Political Science. Completing an internship is optional, but hotly sought after by all majors. A senior capstone monograph, an independent inquiry and writing project crowning the four years, is mandatory for all majors.

Student entrance exams for Political Science are held twice a year with 50 openings per semester. Most of our students are drawn from Brasília's Federal District or the surrounding state of Goiás, but an increasing share comes from more distant states. The program also has a sizeable annual contingent from abroad, principally from Cape Verde, Angola, and Moçambique. By the end of 2008, the undergraduate Political Science program settled at about 400 majors. 
reinforces an already failed nineteenth-century model of university teaching. Students arrive at university socialized into passivity and replicate their role as receptors and consumers of information. Professors unfairly assume the role of oppressors shouldering nearly all of the responsibility for the success of teaching and learning.

\section{The Concept of Competences in (and Around) Political Science}

Working in this kind of setting for over twenty years, and becoming more and more dissatisfied with his own teaching, the primary author became convinced of the need to fight for an alternative vision of teaching and learning. Two comparative observations about the U.S. and Brazilian teaching and learning contexts seem important. First, our curriculum is content-centered and content-heavy. Our more populous student body works through a major comprised of 40 to 50 courses, as compared with the 8 to 12 of American programs. There are so many courses to be offered continuously for so many students. Our students, already cognitively biased against "deep reading" (and without time to read), move from semester to semester acquiring more subject matter, but not necessarily more intellectual autonomy or the ability and motivation for independent and creative thinking. Second, emphasizing the teaching of abilities and capacities that make learning autonomous and students co-responsible in the process of education seems to escape professionals in both countries. The avalanche of content in the information age and makes it difficult for us to think of education as a process of acquiring capabilities, talents, and values as political scientists.

For both professors and students, the current teaching and learning model has become visibly unsustainable, thus delegitimizing the whole educational process. Since the adoption of Brazil's new democratic Constitution of 1988, higher education experienced a paradigmatic shift. Complex evaluation programs were developed to measure teaching activity, conceived primarily as "instruction". This conception, however, confuses means and ends. "Instruction" and "learning" as means and methods become transformed in ends or purposes. To say that the purpose of the university is to offer instruction is like saying that the business of General Motors is to operate assembly lines or that the purpose of medical assistance is to fill hospital beds. The mission should be understood not as instruction, but the realization of learning by students. In truth, we observe that instruction and learning are not necessarily related. 
In the "instruction paradigm", everyone works more and probably learns less as individuals and institutions (more classes, more students, more incentive to cling to passive methods of teaching, costs and budgetary investments). If students aren't learning to solve problems or think critically, old logic dictates that someone should give a lesson or a course on critical thinking and make it a general education requirement. ${ }^{42}$ The reasoning is aggravatingly circular. What the students are learning in the classroom does not address their necessities or those of their professors. Thus, the solution is to call everyone back into the classroom and "instruct" them a little bit more. The result is never the one we expect since critical thinking is taught in largely the same way that other courses are traditionally taught: Excessive lecturing and insufficient time for practice. Teaching is reduced to the process of transferring the professor's knowledge to passive and receptive students. The absolute, necessary, and sufficient condition for this to work is the professor's complete mastery of content. The classroom is a place to realize a long series of talks where students listen to the professor usually in silence and in sullen competition with each other.

If we insist on the "learning paradigm" for education, we frame teaching in a more holistic way by recognizing that the principal agent in the process is the student, not the instructor. Students must be transformed to be discoverers and builders of their own active knowledge. Knowledge in this sense consists of structures that are created or built by the student. Knowledge is not seen as cumulative or linear (like bricks in a wall), but as a field of constant interactions. ${ }^{43,44}$ In this perspective, knowledge is actively constructed, discovered, reworked, and amplified by the students. The efforts of the professor are directed at developing competences and talents among students, not just the dispensing of contents. Teaching and learning is a personal transaction between students and between the students and their professors.

Thinking of teaching and learning as the development and acquisition of particular skills and talents is not particularly new. In research methods courses, for example, we hope to train our students to be literate in a range of methods and techniques that will empower them to do independent inquiry. But generally, Political Science has not acknowledged or systematically

${ }^{42}$ David W Johnson, Roger T. Johnson, and Edythe Johnson Holubec, "New Circles of Learning," Change, 1994.

${ }^{43}$ Robert B. Barr, and John Tagg, "A New Paradigm for Undergraduate Education," Change, November/December (1995).

${ }^{44}$ David W. Johnson, Roger T. Johnson, and Edythe Johnson Holubec, Cooperation in the Classroom (Boston: Allyn and Bacon, 1998). 
adopted the notion of competence-based teaching and learning emanating from the Bologna Process and the evolving Tuning Project of the European Commission. Recent scholarship describes and implicitly admires the Process, but does not seem to recommend this movement for Political Science. ${ }^{45,46,47}$

On the other hand, work on teaching and learning in Political Science has perhaps always flirted with the notion of competences, although we seldom use the term. The evolution of the literature since it began to focus scientifically on teaching and learning ${ }^{48,49,50}$ stimulated a serious reflection what is now a "growth field". ${ }^{51,52}$ In U.S. Political Science, there is abundant discussion of course bibliography, syllabi, and diverse experiments in the pages of the old newspaper-format encarta Political Science Teacher (1973-89) as well as current PS: Political Science \& Politics, the Journal of Political Science Education (its main mission), and Perspectives on Politics (although only occasionally).

But if we review the content of the three major publications where teaching has been studied since the late 1990s/2000s, competences appear in the guise of "best practices". ${ }^{53}$ For example, there is much presentation and

${ }^{45}$ Marijk C Van der Wende, "The Bologna Declaration: Enhancing the Transparency and Competitiveness of European Higher Education," Higher Education in Europe 25, no 3 (2000): 305-310.

${ }^{46}$ Steven D Roper, "European Education Reform and Its Impact on Curriculum and Admissions: Implications of the Bologna Process on United States Education," Journal of Political Science Education 3, no 1 (2007): 51-60.

${ }^{47}$ Bob Reinalda, "The Bologna Process and Its Achievements in Europe 1999-2007," Journal of Political Science Education 4, no 4 (2008): 463-476.

${ }^{48}$ Marijke Breuning, Paul Parker, and John T. Ishiyama, "The Last Laugh: Skill Building through a Liberal Arts Political Science Curriculum," PS: Political Science \& Politics 34 (2001): 657-661.

49 Jenny Kehl, "Indicators of the Increase of Political Science Scholarship on Teaching and Learning in Political Science," PS: Political Science \& Politics 35 (2002): 229-232.

${ }^{50}$ Pat Hutchings, Chris Bjork, and Marcia Babb, "The Scholarship of Teaching and Learning in Higher Education: An Annotated Bibliography," PS: Political Science \& Politics 35 (2002), 233-236.

${ }^{51}$ Kerstin Hamann, Philip H. Pollock, and Bruce M. W, "Who SoTLs Where? Publishing the Scholarship of Teaching and Learning in Political Science," PS: Political Science \& Politics 42 (2009): 729-735.

52 John Craig, "What Have We Been Writing About?: Patterns and Trends in the Scholarship of Teaching and Learning in Political Science," Journal of Political Science Education 10, no 1 (2014): 23-36.

${ }_{53}$ John Craig's (2014) excellent assessment draws our attention to other journals where we might expect competence-based teaching and learning to appear more overtly: International Studies Perspectives, European Political Science, Learning and Teaching: The International 
evaluation of innovative projects or courses reflecting the lines of APSA Teaching and Learning Conferences. But some of these experiences, if looked at another way, could be considered analyses and advocacies of competences. In government and public policy courses, competences appear as "problem-based learning" (PBL). ${ }^{54,55}$

In the Political Science assessment literature, "student learning outcomes" (SLOs) might act as surrogates for competences both generic and specific. ${ }^{56}$ In various settings a concern is presented for developing critical thinking skills. ${ }^{57,58,59}$ Writing competence is also a recurring emphasis. ${ }^{60,61}$ Learning to work collaboratively might be perceived as an important competence for the young political scientist. ${ }^{62,63}$ And, yes, information literacy ${ }^{64}$ through

Journal of Higher Education (LATISS, 2004 - ), and Enhancing Learning in the Social Sciences (EliSS, 2008 - ). See also McClellan and Maurer ("After Wahlke") who insinuate that curriculum and competences may be creeping into U.S. academic discourse.

${ }^{54}$ Jonathan Williamson and Alison S. Gregory, "Problem-Based Learning in Introductory American Politics Classes," Journal of Political Science Education 6, no 3(2010): 274-296.

${ }_{55}$ Heidi M Berggren, "Problem-Based Learning and Improved Learning Outcomes in 'The Politics of Welfare Reform', Journal of Political Science Education 7, no 4(2011): 434453.

${ }^{56}$ Christopher K Butler, "Comparing Curricula and Assessment Processes of B.A. Programs in Political Science" (paper presented at the APSA 11th Teaching and Learning Conference, Philadelphia, February 7-9, 2014).

${ }^{57}$ Leanne C Powner, "Teaching the Scientific Method in the Active Learning Classroom," PS: Political Science \& Politics 39 (2006): 521-524.

${ }^{58}$ Mark Souva, "Fostering Theoretical Thinking in Undergraduate Classes," PS: Political Science \& Politics 40 (2007): 557-561.

${ }^{59}$ Jennifer Fitzgerald and Vanessa A. Baird, "Taking a Step Back: Teaching Critical Thinking by Distinguishing Appropriate Types of Evidence," PS: Political Science \& Politics 44 (2011): 619-624.

${ }^{60}$ Michelle Hale Williams, Kymberly Anne Goodson, and W. Gary Howard, "Weighing the Research Paper Option: The Difference that Information Literacy Can Still Make," PS: Political Science \& Politics 39 (2006): 513-519.

${ }^{61}$ Yvette M Alex-Assensoh, "Teaching Critical Analysis Skills with Analysis Briefs: What They are and How They Work," PS: Political Science \& Politics 41 (2008): 189-192.

${ }_{62}$ Angela Wolfe, "Implementing Collaborative Learning Methods in the Political Science Classroom," Journal of Political Science Education 8, no 4 (2012): 420-432.

${ }_{63}$ Tracy H. Slagter and Druscilla L. Scribner, "Interteach and Student Engagement in Political Science,” Journal of Political Science Education 10, no 1 (2014): 81-92.

${ }^{64}$ Robert Burnhein, "Information Literacy-A Core Competency," Australian Academic \& Research Libraries 23, no 4 (1992): 188-196. 
harnessing the Internet as a research tool ${ }^{65,66}$ and perhaps even taming Wikipedia $^{67}$ and Google ${ }^{68}$ to our ends!

What of political scientists? How can we engage the question of competence-based teaching and learning directly? This has clearly been the thrust of the Europeans first through the Tuning Educational Structures in Europe (since 2001) and now the Latin Americans (since 2004) via the ALFA Tuning Project. ${ }^{69}$ Basically, these projects seek to: 1) create disciplinebased networks to foment innovation and quality; 2) encourage a greater consensus (but not uniformity) in defining professional standards and learning outcomes; 3) to facilitate transparency and communication of best practices; and 4) "tune" university degrees along the "Lines" of general and academic skills, knowledge, core curricula and content, the ECTS as an accumulation system, and methods of teaching and learning, assessment and performance, and quality.

Besides focusing on curricular, transfer credit questions, and assessment, the main issue for the Latin Americans is the pillar of competences, defined as:

... including the capacities that all humans need to resolve the situations that arise in their lives effectively and autonomously. It is grounded on a deep knowledge - not only knowing what and how, but knowing how to be a person in a complex, changing and competitive world. Another definition suggests that competencies are "complex integrated capacities, in different degrees, in which education must train individuals so that they can operate as responsible subjects in different situations and contexts of their social and personal life, knowing how to see, do, act and enjoy properly, assessing

${ }^{65}$ Andrew M. Robinson and Karen Schlegl, "Student Use of the Internet for Research Projects: A Problem? Our Problem? What Can We Do About It?," PS: Political Science \& Politics 38 (2005): 311-315.

${ }^{66}$ Daniel M. Butler, Richard J. Butler, and Jesse T. Rich, "The Equalizing Effect of the Internet on Access to Research Expertise in Political Science and Economics," PS: Political Science \& Politics 41 (2008): 579-584.

${ }^{67}$ Adam R Brown, "Wikipedia as a Data Source for Political Scientists: Accuracy and Completeness of Coverage," PS: Political Science \& Politics 44 (2011): 339-343.

${ }_{68}$ Stephen Thornton, "From "Scuba Diving" to "Jet Skiing"? Information Behavior, Political Science, and the Google Generation," Journal of Political Science Education 6, no 4 (2010): 353-368.

${ }^{69}$ For more historical background on Bologna and the various and outcomes of Tuning and Alfa Tuning Latin America consult Wächter ("The Bologna Process: Developments and Prospects"), González and Wagenaar (Tuning Educational Structures in Europe. Final Report; Tuning Educational Structures in Europe), and Beneitone et al. (Reflections on and Outlook for Higher Education in Latin America), respectively. 
alternatives, choosing appropriate strategies and taking responsibility for the decisions taken. ${ }^{70}$

As such, competence-based education orients teaching to integrating formal and informal learning, everyday, academic, and scientific knowledge. Education is viewed as encompassing knowledge (cognitive capacity), abilities (sensory-motor capacity), skills, attitudes, and values. In other words,

... competence in education sits within a broad conceptual map of the comprehensive education of the citizen, including new approaches, such as significant learning in different areas: cognitive (knowing), psychomotor (know-how, skills), emotional (savoir-être), attitudes and values. ... Competencies develop gradually through different levels of complexity, in different types: basic or fundmental, generic or common, specific or targeted and career-oriented. ${ }^{71}$

Competences represent in dynamic form the combined processes of teaching and learning along with the development of practices and abilities. Considered at the level of individual courses, they become learning objectives or desired outcomes. But they cannot be measured in a before-and-after fashion like content. Competences are transversal, i.e., they ideally run through various courses in the curriculum and develop long-term.

This seems like a definition of education that the teaching and learning communities of Political Science could easily accept and elaborate. Of course, assuming a competence perspective requires the redesign, redevelopment, and reassessment of Political Science curricula. Could it be possible that as a discipline we could converge around a vision of a "metaprofile" of a political scientist we hope to create? This is happening now in Latin America in 19 countries spanning 12 fields of study. Through extensive and intensive discussion and survey validation of 27 generic competences with students, professors, graduates, and employers with a total of about 22,600 questionnaire responses, various fields and universities are embarking on the same path of curricular compatibility (but not uniformity) as the Europeans.

${ }^{70}$ Pablo Beneitone et al., Reflections on and Outlook for Higher Education in Latin America. Final Report - Tuning Latin America Project 2004-2007 (Bilbao: University of Deusto and University of Groningen, 2007), 31.

${ }^{71}$ Beneitone et al., Reflections on and Outlook for Higher Education, 32. 
Political Science was not one of fields initially included for consideration in Europe or Latin America. ${ }^{72}$ Law and History are perhaps the closest disciplinary cousins that are participating. Let us turn to Law for inspiration. ${ }^{73}$

\section{Proposed Metaprofile for Debate and Research}

During the first academic term of 2014, the primary author offered a course called "Special Topics in Political Science 2: Teaching and Learning in Political Science" at the undergraduate level. Along with the student coauthors of this paper, we reviewed the historiography of Political Science in the U.S. and Brazil with an eye towards detecting or fomenting a more selfcritical professional attitude. We worked in seminar fashion through much of review literature cited here as well as ALFA Tuning Latin America

${ }^{72}$ ALFA Tuning Latin America has published the theory and research that yielded a metaprofile for each area: Rodríguez (2013) for History, Cárdenas (Ensino Superior na América Latina) for Psychology, Montaño López (Ensino Superior na América Latina) for Education, Cáceres (Ensino Superior na América Latina) for Administration, and Felix (Educação Superior na América Latina) for Law. Beneitone et al. (Meta-perfiles y perfiles) summarizes results on metaprofiles of all of the 15 contemplated areas in Latin America. The publications cited in our reference list are in Spanish or Portuguese, but all are or soon will be available in English on the main Tuning website (http://www.unideusto.org/tuningeu/).

73 The Law School is the epicenter of competence-based curricular reform at the University of Brasília. As Political Science and Law shared the same building on campus for over twenty years, the primary author found it impossible to ignore what was happening in one of the most hamstrung and stodgy of the disciplines. He also participates in the Law School's MA and PhD programs and was gradually immersed in the debates between and among professors and students. The key player in the competence movement was a law professor who, not coincidentally, coordinated the area of Law in Latin America for the ALFA Tuning Project since 2004. Previously, she had been part of earlier curricular discussions and initiatives circulating with the Ministry of Education and the Brazilian Bar Association since the mid1990s.

The School finalized their proposal for University administration approval this year. The process and the outcome of two years of work yielded a striking departure for the law degree, universally recognized in Brazil as formalistic, conservative, and nationally uniform in structure and content. The model that will likely be implanted over the next few years reduces the number of required courses by half, institutes research seminars as a course requirement, and mandates service learning at the undergraduate level. Professors will teach fewer courses, probably be able to publish more (with their students), and students will learn more and with greater confidence.

The competence approach was a difficult "sell" at first, especially among the professors. Even some students would prefer that the curriculum remains the way it is. But the approach has clearly established a presence (Felix, "O Projeto ALFA Tuning e a área de Direito") and syllabi and course activities are being "tuned" around the notion of competence outcomes. 
publications. We had two or three contentious meetings where we hammered out a proposal of generic competences for Political Science with a view towards creating an advocacy group for the approach within the Undergraduate Program. This excursion into subversive Political Science resulted in this text to which we now welcome readers' reactions.

We propose a more systematic discussion of competence-based teaching and learning in Political Science, perhaps drawing on the Law-Latin America lists of generic and specific competences (see Figures 1 and 2). We did not propose to substitute words "Law" and "lawyers" with "Political Science" and "political scientists" in these lists. Rather, we viewed them as examples of how a profession can critically de- and reconstruct its cognitive and behavioral building-blocks to arrive at a wider vision of teaching and learning.

Figure 1

\section{Generic Competences for Law (Latin America)}

1) Capacity to identify, formulate, and resolve problems by applying knowledge.

2) Capacity for organization and planning.

3) Social responsibility and commitment to citizenship.

4) Capacity to communicate disciplinary knowledge in distinct contexts.

5) Capacity to research, process, and analyze information from a variety of sources.

6) Capacity to learn and update learning permanently.

7) Critical and self-critical capacities.

8) Capacity to react to new situations creatively.

9) Capacity to make reasoned decisions.

10) Capacity to work as part of a team, motivating and facilitating common goals.

11) Interpersonal abilities.

12) Commitment to environmental preservation.

13) Valuation and respect for diversity and multiculturality.

14) Ethical committment.

15) Committment to quality.

Source: Translated and adapted from Felix. ${ }^{74}$

${ }^{74}$ Loussia P. M Felix, Educação Superior na América Latina: reflexões e perspectivas em Direito (Bilbao: Universidad de Deusto, 2014), 20. 
Figure 2

Subject Specific Competences for Law (Latin America)

1) Identify, interpret, and apply the general principles and rules national and international judicial systems in concrete cases.

2) Evaluate axiologically possible courses of action within the judicial system.

3) Commitment to human rights and the democratic rule of law.

4) Capacity to work in teams in your own area of expertise and in interdisciplinary teams, enriching the commitment to the law and the solution of complex cases.

5) Capacity reason, argue, and decide juridically.

6) Promote a culture of dialogue and the use of alternative means of conflict resolution.

7) Dominate the required languages necessary for the exercise of the profession in a globalized and multicultural context.

8) Apply appropriate methodologies in legal research.

9) Capacity to critically analyze relevant juridical situations and contribute to the creation of juridical institutions and solutions in general and in specific cases.

10) Capacity to elaborate texts express oneself in fluent technical language, using precise and clear legal terms.

11) Capacity to act validly and effectively in different administrative and judicial instances.

12) Capacity to decide if the factual circumstances are sufficiently clear so as to lead to a sound legal decision.

13) Act ethically in the exercise of one's professional functions.

Source: Translated and adapted from Felix. ${ }^{75}$

We feel our reflections are tentative and insufficient at this point and we do not propose a closed set of competences for adoption. Instead, we propose for debate that the Political Science teaching and learning community, perhaps under Tuning auspices, organize specific and systematic examinations of the advantages and disadvantages of adopting competence-based teaching and learning for Political Science along the lines of the various Tuning experiences. This examination might take various forms, e.g., future professional association panels or roundtables or contact and discussion with similarly-minded forums.

Figure 3 is offered to the Tuning (and non-Tuning Political Science) community in this spirit.

${ }^{75}$ Felix, Educação Superior na América Latina, 21. 
Figure 3

Proposed Generic Competences for Political Science

1) Capacity to identify, formulate, and resolve problems by applying knowledge.

2) Capacity for organization and planning academic and professional activities, both individual and collective.

3) Socio-environmental responsibility and commitment to citizenship and democratic values.

4) Capacity to communicate disciplinary knowledge in distinct contexts.

5) Capacity to research, process, and critically analyze information from a variety of sources.

6) Capacity to learn and update learning permanently.

7) Capacity to react to new intellectual, political, and social situations creatively.

8) Capacity to work as part of a team, motivating and facilitating common goals.

9) Valuation and respect for diversity and multiculturality.

10) Ethical committment as an intellectual and citizen.

Source: Student-led deliberations in Special Topics in Political Science 2: Teaching and Learning in Political Science (First Semester 2014, IPOL/UnB)

As educators, as we focus on developing these capacities in our students, we will have to think about how (both inside and outside the classroom) we would address what knowledge, what abilities, what attitudes, and what values will be developed through the curriculum at strategic moments. Curriculum is not the only component of a pedagogical project; curriculum is conflated with courses. Teaching is not just a question of transmitting content; content is outdated the moment our students graduate (if not before). Curriculum generally and erroneously equates content with the development of competencies, the fundamental and long-term goal of education.

Political Science must radically shift its emphasis and methods of teaching and learning from content to competencies. Modeled on the work of the Tuning Project of the European Commission and related experiences in Brazil, this paper offered a modest initial proposal for rethinking the teaching and learning of Political Science at the undergraduate level. Comparisons, contrasts, and reflections were drawn from the examples of the Political Science Program and the Law School at the University of Brasília. 


\section{Bibliography}

Abrami, Philip C., Gretchen Lowerison, and Eva M Bures. "Introduction to the Special Issue on Postsecondary Instruction: The Old Science of Phrenology and the New Science of College Teaching." Educational Research and Evaluation: An International Journal on Theory and Practice 10, no 4-6 (2004): 289-301.

Alex-Assensoh, Yvette M. "Teaching Critical Analysis Skills with Analysis Briefs: What They are and How They Work." PS: Political Science \& Politics 41 (2008): 189-192.

Anderson, Lisa. "Too Much Information? Political Science, the University, and the Public Sphere." Perspectives on Politics 10 (2012): 385-396.

Araújo, Cícero, and San R Assumpção. "Teoria Política no Brasil Hoje." In Horizontes das Ciências Sociais no Brasil: Ciência Política, edited by Carlos Benedito Martins and Renato Lessa, 51-58. São Paulo: ANPOCS, 2010.

Barr, Robert B., and John Tagg. "A New Paradigm for Undergraduate Education." Change, November/December 1995.

Beneitone, Pablo, César Esquetini, Júlia González, Maida Marty Maletá, Gabriela Siufi, and Robert Wagenaar, eds.. Reflections on and Outlook for Higher Education in Latin America. Final Report - Tuning Latin America Project 20042007. Bilbao: University of Deusto and University of Groningen, 2007.

Beneirotone, Pablo, César Esquetini, Júlia González, and Robert Wagenaar, eds. Meta-perfiles y perfiles. Una nueva aproximación para las titulaciones en América Latina. Bilbao: University of Deusto, 2014.

Berggren, Heidi M. "Problem-Based Learning and Improved Learning Outcomes in 'The Politics of Welfare Reform'." Journal of Political Science Education 7, no 4 (2011): 434-453.

Berman, Marc G., John Joanides, and Stephen Kaplan. "The Cognitive Benefits of Interacting with Nature.” Psychological Science 19, no 12 (2008): 1207-1212.

Breuning, Marijke, Paul Parker, and John T. Ishiyama. "The Last Laugh: Skill Building through a Liberal Arts Political Science Curriculum.” PS: Political Science \& Politics 34 (2001): 657-661.

Brown, Adam R. "Wikipedia as a Data Source for Political Scientists: Accuracy and Completeness of Coverage." PS: Political Science \& Politics 44 (2011): 339343.

Burnhein, Robert. "Information Literacy - A Core Competency." Australian Academic \& Research Libraries 23, no 4 (1992): 188-196.

Butler, Christopher K. "Comparing Curricula and Assessment Processes of B.A. Programs in Political Science." Paper presented at the APSA 11th Teaching and Learning Conference, Philadelphia, February 7-9, 2014.

Butler, Daniel M., Richard J. Butler, and Jesse T. Rich. "The Equalizing Effect of the Internet on Access to Research Expertise in Political Science and Economics." PS: Political Science \& Politics 41 (2008): 579-584.

Cáceres, César Esquetini. Ensino Superior na América Latina: reflexões e perspectivas sobre Administração. Bilbao: Universidad de Deusto, 2014. 
Cárdenas, Diego E. R. Ensino Superior na América Latina: reflexões e perspectivas sobre Psicologia. Bilbao: Universidad de Deusto, 2014.

Carr, Nicholas. "Is Google Making Us Stupid?” Atlantic Monthly (2008).

. The Shallows: What the Internet Is Doing to Our Brains. New York: W.W. Norton \& Company, 2011.

Connor, Charles E., Howard Egeth E., and Steven Yantis. "Visual Attention: Bottom-Up versus Top-Down." Cognitive Biology 14 (2004): 850-52.

Cox, Sean Michael. "In the Pits: Teaching from the Bottom Up." PS: Political Science \& Politics 36 (2003): 75-76.

Craig, John. "What Have We Been Writing About?: Patterns and Trends in the Scholarship of Teaching and Learning in Political Science." Journal of Political Science Education 10, no 1 (2014): 23-36.

DeStefano, Diana, and Jo-Anne LeFevre. "Cognitive Load in Hypertext Reading: A Review." Computers in Human Behavior 23, no 3 (2007): 1616-1641.

dos Santos, Wanderley Guilherme. "A Ciência Política na América Latina (notas preliminares de autocrítica).” Dados 23, no 1 (1980): 15-27.

Driver, Darrell, Kyle Jette, and Leonard Lira. "Student Learning Identities: Developing a Learning Taxonomy for the Political Science Classroom.” Journal of Political Science Education 4, no 1 (2008): 61-85.

Evans, James A. "Electronic Publication and the Narrowing of Science and Scholarship.” Science 321 (2008): 395-399.

Felix, Loussia P. M. "O Projeto ALFA Tuning e a área de Direito: competências como eixo da formação na perspectiva latino-americana." Notícia do Direito Brasileiro 13 (2006): 197-222.

- Educação Superior na América Latina: reflexões e perspectivas em Direito. Bilbao: Universidad de Deusto, 2014.

Fitzgerald, Jennifer, and Vanessa A. Baird. "Taking a Step Back: Teaching Critical Thinking by Distinguishing Appropriate Types of Evidence." PS: Political Science \& Politics 44 (2011): 619-624.

Gardner, Howard and Katie Davis. The App Generation: How Today's Youth Navigate Identity, Intimacy, and Imagination in a Digital World. New Haven: Yale University Press, 2013.

González, Julia, and Robert Wagenaar. Tuning Educational Structures in Europe Final Report - Pilot Project Phase 1. Bilbao: Universidad de Deusto, 2013.

González, Julia, and Robert Wagenaar. Tuning Educational Structures in Europe Universities Contribution to the Bologna Process. Bilbao: Universidad de Deusto, 2005.

Groth, Terrie R. "Diagnosing and Treating the Radical Malaise." Paper presented at the XVIth International Congress of the Latin American Studies Association, Washington, DC, April 4-6, 1991.

—. "Rethinking Political Science as Discipline: Teaching and Learning at the University of Brasília." Paper prepared for delivery at the 2000 Annual Meeting of the American Political Science Association, Marriott Wardman Park Hotel, Washington, DC, August 31-September 3, 2000. 
. "The Case for Competency-Based Teaching and Learning in Political Science." Paper presented at the APSA 11th Teaching and Learning Conference, Philadelphia, February 7-9, 2014.

Hamann, Kerstin, Philip H. Pollock, Philip H., and Bruce M. W. "Who SoTLs Where? Publishing the Scholarship of Teaching and Learning in Political Science.” PS: Political Science \& Politics 42 (2009): 729-735.

Hartlaub, Stephen G., and Frank A. Lancaster. "Teacher Characteristics and Pedagogy in Political Science." Journal of Political Science Education, 4, no 4 (2008) 377-393.

Hutchings, Pat, Chris Bjork, and Marcia Babb. "The Scholarship of Teaching and Learning in Higher Education: An Annotated Bibliography." PS: Political Science \& Politics 35 (2002): 233-236.

Jackson, Maggie . Distracted: The Erosion of Attention and the Coming Dark Age. Amherst, NY: Prometheus, 2008.

Johnson, David W., Roger T. Johnson, and Edythe Johnson Holubec. "New Circles of Learning." Change, 1994.

. Cooperation in the Classroom. Boston: Allyn and Bacon, 1998.

Kandel, Eric R. In Search of Memory: The Emergence of a New Science of Mind. New York: Norton, 2006.

Kehl, Jenny. "Indicators of the Increase of Political Science Scholarship on Teaching and Learning in Political Science." PS: Political Science \& Politics 35 (2002): 229-232.

Klingberg, Torkel. The Overflowing Brain:Information Overload and the Limits of Working Memory. Translation by Neil Betteridge. Oxford: Oxford University Press, 2009.

Lamounier, Bolivar. "Pensamento Político, Institucionalização Acadêmica e Relação de Dependência no Brasil.” Dados 23, no 1 (1980): 29-57.

—. "A Ciência Política no Brasil: Roteiro para um Balanço Crítico." In A Ciência Política nos Anos 80, edited by Bolivar Lamounier, 407-433. Brasília, DF: Editora UnB, 1982.

LeDoux, Joseph. Synaptic Self: How Our Brains Become Who We Are. New York: Penguin, 2002.

Lessa, Renato. "OCampo da Ciência Política no Brasil: uma Aproximação Construtivista." In Horizontes das Ciências Sociais no Brasil: Ciência Política, edited by Carlos Benedito Martins e Renato Lessa, 13-49. São Paulo: ANPOCS, 2010.

McClellan, E. Fletcher and Brianna Maurer. “After Wahlke: New Models for Organizing the Undergraduate Political Science Major and the Prospects for Reform." Paper presented at the APSA 11th Teaching and Learning Conference, Philadelphia, February 7-9, 2014.

Montaño López, Ana María. Ensino Superior na América Latina: reflexões e perspectivas sobre Educação. Bilbao: Universidad de Deusto, 2014.

Niederhauser, D. S., Reynolds, R. E., Salmen, D. J. and P. Skolmoski. “The Influence of Cognitive Load on Learning from Hypertext." Journal of Educational Computing Research 23, no 3 (2000): 237-255. 
Nielsen, Jakob. "F-Shaped Pattern fo Reading Web Content." Alertbox, 2006. Accessed April 17, 2015. www.useit.com/alertbox/reading_pattern.html.

—. "How Little Do Users Read?" Alertbox, 2008. Accessed May, 62015. www.useit.com/alertbox/percent-text-read.html.

Niyíri, J.C. "Thinking with a Word Processor." In Philosophy and the Cognitive Sciences, edited by R. Casati. Vienna: Hölder-Pichler-Tempsky, 1994.

Powner, Leanne C. "Teaching the Scientific Method in the Active Learning Classroom.” PS: Political Science \& Politics 39 (2006): 521-524.

Reinalda, Bob. "The Bologna Process and Its Achievements in Europe 1999-2007." Journal of Political Science Education 4, no 4 (2008): 463-476.

Reis, Fábio W. “O Grifo É Nosso! Academia, Democracia e Dependência.” Dados 23, no 1 (1980): 59-77.

Robinson, Andrew M., and Karen Schlegl. "Student Use of the Internet for Research Projects: A Problem? Our Problem? What Can We Do About It?" PS: Political Science \& Politics 38 (2005): 311-315.

Rodríguez, Darío C. Educación Superior en América Latina: reflexiones y perspectivas en Historia. Bilbao: University of Deusto, 2013.

Roper, Steven D. "European Education Reform and Its Impact on Curriculum and Admissions: Implications of the Bologna Process on United States Education." Journal of Political Science Education 3, no 1 (2007): 51-60.

Rouet, Jean-François, and Jarmo J. Levonen. "Studying and Learning with Hypertext: Empirical Studies and Their Implications." In Hypertext and Cognition, edited by Levonen Rouet, Andrew Dillon, and Rand J. Spiro. Mahwah, NJ: Erlbaum, 1996.

Slagter, Tracy H., and Druscilla L. Scribner. "Interteach and Student Engagement in Political Science.” Journal of Political Science Education 10, no 1 (2014): 8192.

Small, Gary, and Gigi Vorgan. iBrain: Surviving the Technological Alteration of the Modern Mind. New York: Collins, 2008.

Small, Gary, TD Moody, P Siddarth, and SY Bookheimer. "Your Brain on Google: Patterns of Cerebral Activation during Internet Searching." American Journal of Geriatric Psychiatry 17, no. 2 (2009): 116-126.

Souva, Mark. "Fostering Theoretical Thinking in Undergraduate Classes." PS: Political Science \& Politics 40 (2007): 557-561.

Spina Forjaz, Maria Cecília. “A Emergência da Ciência Política Acadêmica no Brasil: Aspectos Institucionais.” Revista Brasileira de Ciências Sociais 35 (1997): 101-120.

Thornton, Stephen. "From "Scuba Diving" to "Jet Skiing"? Information Behavior, Political Science, and the Google Generation." Journal of Political Science Education 6, no 4, (2010): 353-368.

Trent, John E. "Political Science 2010: Out of Step with the World? Empirical Evidence and Commentary." Paper prepared for the $21^{\text {st }}$ International Pòlitical Science Association World Congress, Santiago, Chile, July, 2009. 
_ . "Should Political Science Be More Relevant? An Empirical and Critical Analysis of the Discipline.” European Political Science 10 (2011): 191-209.

Van der Wende, Marijk C. "The Bologna Declaration: Enhancing the Transparency and Competitiveness of European Higher Education." Higher Education in Europe 25, no 3 (2000): 305-310.

Wächter, Bernd. "The Bologna Process, Developments and Prospects." European Journal of Education 39, no 3 (2004): 265-273.

Wexler, Bruce E. Brain and Culture: Neurobiology, Ideology, and Social Change. Cambridge, MA: MIT Press, 2006.

Williams, Michelle Hale, Kymberly Anne Goodson and W. Gary Howard. "Weighing the Research Paper Option: The Difference that Information Literacy Can Still Make." PS: Political Science \& Politics 39 (2006): 513-519.

Williamson, Jonathan and Alison S. Gregory. "Problem-Based Learning in Introductory American Politics Classes." Journal of Political Science Education 6, no 3 (2010): 274-296.

Winner, Langdon. "Technologies as Forms of Life." In Readings in the Philosophy of Technology, edited by David M. Kaplan. Lanham, MD: Rowman \& Littlefield, 2004.

Wolfe, Angela. "Implementing Collaborative Learning Methods in the Political Science Classroom.” Journal of Political Science Education 8, no 4 (2012): 420432.

Young, Iris Marion. "Political Theory: An Overview." In A New Handbook of Political Science, edited by Robert E. Goodin and Hans-Dieter Klingemann, 479-502. Oxford: Oxford University Press, 1996.

\section{Copyright}

Copyright for this article is retained by the Publisher. It is an Open Access material that is free for download, distribution, and or reuse in any medium only for non-commercial purposes; provided any applicable legislation is respected, the original work is properly cited, and any changes to the original are clearly indicated. 